\section{Frequency and characteristics of induced abortion among married and single women in São Paulo, Brazil}

\author{
Aborto provocado: sua dimensão e características \\ entre mulheres solteiras e casadas da cidade \\ de São Paulo, Brasil
}

\section{${ }_{1}^{1}$ Departamento de Medicina Preventiva, Universidade Federal de São Paulo, São Paulo, Brasil. \\ 2 Faculdade de Medicina de Ribeirão Preto, Universidade de São Paulo, Ribeirão Preto, Brasil. \\ Correspondence E. M. Vieira \\ Departamento de Medicina Social, Faculdade de Medicina de Ribeirão Preto, Universidade de São Paulo. Av. dos Bandeirantes 3900 , 2o andar, Ribeirão Preto, $S P$ 14049-900, Brasil. bmeloni@fmrp.usp.br}

\section{Abstract}

This article presents the results of a study in the city of São Paulo, Brazil, aimed at estimating the frequency of induced abortion among women 15 to 49 years of age. The objective was to characterize the occurrence of induced abortion by comparing the ideal number of children, age, and contraceptive use between married and single women. Based on random sampling, 1,749 interviews were held, including 764 married women, 658 single women, and 327 with other marital status. The analysis included: mean number of abortions per woman by analysis of variance and proportions of abortions and pregnancy, using the chi-square test. The mean abortion rate for married women (45 per thousand) did not differ statistically from that of single women. However, the pregnancy rate was much lower in single women, and when single women became pregnant they used abortion more frequently; while fewer than $2 \%$ of pregnancies in married women ended in induced abortions, among single women the abortion rate exceeded $18 \%$. Therefore, the priority in the reproductive health field should be to invest in the supply and dissemination of appropriate contraceptive methods for women's early sexually active life.

Induced Abortion; Contraceptive Agents; Reproductive Health
Rebeca de Souza e Silva 1

Elisabeth Meloni Vieira 2

\section{Introduction}

Abortion is a major public health problem in Brazil 1, especially since it is one of the principal causes of maternal mortality 2, and most of these deaths are avoidable 3,4 . Abortion is currently considered a silent pandemic that calls for imperative public health and human rights measures 5

Brazilian legislation only allows abortion when the pregnancy poses a threat to the woman's life or has resulted from rape, and even in these limited situations, various reports indicate great reluctance by health professionals and difficulty by women in obtaining legal abortion within the public health care system $6,7,8$.

The restricted legality of induced abortion in Brazil contrasts with the reality of an estimated 750 thousand to one million abortions per year. Some 250 thousand annual cases of hospitalizations in the Unified National Health System (SUS) are known to occur for complications due to abortion ${ }^{3}$. The deficient supply of contraceptive methods by the National Health System has been identified as a major factor contributing to clandestine abortion.

In 1987, a household survey was carried out in the Vila Madalena neighborhood in the city of São Paulo, Brazil, to measure and characterize the occurrence of abortion, concluding that young, single women used induced abortion the most 9 . In 1993, using the same methodol- 
ogy, a study was held with 1,749 women living in the city of São Paulo, detecting a trend identical to that of the previous study, i.e., that young, single women without children, who use ineffective contraceptive methods (especially condoms and/or the rhythm method), and that report accepting an abortion under any circumstances are the ones that report the highest induced abortion rates when they become pregnant.

In Vila Madalena, a high-income neighborhood with an extremely low fertility rate, both the mean number of abortions per thousand women and the proportion of abortions per pregnancy were double those observed for the city of São Paulo as a whole. There is thus strong evidence that in a transition from a given fertility rate to a substantially lower rate, i.e., in the process of declining fertility, the use of induced abortion increases sharply.

Additionally, as expected, contraceptive use was more frequent in Vila Madalena than in the city of São Paulo as a whole, consistent with the increasing demand for tubal ligation, which has been the most prevalent contraceptive method for some time in Brazil 10,11. According to Vieira et al. 11, in Brazil as a whole and in the State of São Paulo, women tend to use oral contraceptives until 30 years of age, after which the tubal ligation rate increases. Therefore, induced abortion tends increasingly to be an option for young women during their initial sexually active years and/or outside of a stable marital union.

Both studies also showed (through multivariate analysis) that being in favor of induced abortion weighs heavily as a factor for choosing abortion. The next most important factor is marital status: being married is a highly protective factor - more precisely, married women use abortion substantially less often. Even among women who claim harboring restrictions to abortion, single women use it more often. In other words, in spite of their restrictions, that is, even not being totally in favor of the practice, single women (i.e., not living in a stable marital union) are impelled to turn to abortion when they become pregnant.

In 2000, the Vila Madalena neighborhood was revisited, this time through an indirect (selfcompleted) survey. Although the interviewees' median family income had increased since 1987 and the fertility rate had dropped even further, the profile of women using induced abortion remained the same 12 .

Thus, given the decisive role of marital status for understanding the dynamics of abortion, regardless of place or calendar year, we felt it was important to conduct this analysis considering marital status (married versus single), taking data for the city of São Paulo collected in 1993 as the baseline for subsequent studies using the same instrument and methodology.

\section{Objective}

The objective was to characterize the occurrence of induced abortion as a function of: the gap between the actual number of live births and what the woman defined as her ideal number of children, woman's age, and use of contraceptive methods, separately for married and single women.

\section{Material and methods}

The study population consisted of women at reproductive age (15-49 years) living in the city of São Paulo in 1993. Two household samples were selected using non-probabilistic sampling 13. The maximum size for each sample was 900 interviews - 390 obtained by calculating the sample size in a simple random sample, in which one adopts the value of the maximum variability among the proportions $-0.25-$, multiplied by a factor of 2.25 (called the design effect, and which is usually taken as 1.5). In each block a starting point was randomly selected as well as the route to be followed. Every household beyond that point was visited until nine interviews were completed or the initial household was reached again.

In one sample (876 women), we investigated the incidence of induced abortions in the year prior to the survey (i.e., 1992) with the aid of the randomized response technique (RRT). In the other sample (873 women), the same information was collected using a conventional approach. In the randomized response probabilistic technique, the interviewee answers "yes" or "no" to one of two possible questions, where one relates to the occurrence of abortion and the other to just any question, but with a known and low probability of occurrence, such as "Were you born in the month of April?" (given that the proportion of affirmative answers is slightly less than $1 / 12$, given that there are fewer births in April). The interviewee selected the question, and the interviewer receives the response without knowing which of the two questions is being answered 14,15. RRT, like the ballot-box technique 16, allows a better approach to the object of study when the latter is difficult to reveal.

Half of the women were interviewed with RRT and the other half approached conventionally, directly, with the question: "Did you have an induced abortion in the last year?” In both samples, 
induced abortions over the course of their childbearing years, the central focus of this article, were collected directly, with proper care to avoid jeopardizing the use of RRT.

For the current analysis, of the total of 1,749 women, we excluded 317 that were in commonlaw unions, separated and/or divorced, or widows at the time of the interview. Appropriate statistical tests showed the two samples' homogeneity in relation to the target characteristics: five-year age bracket, number of children, and marital status, as well as homogeneity in relation to data for the city of São Paulo provided by the State Data Analysis System Foundation (SEADE Foundation) 10 . More precisely, the findings obtained for our samples in relation to the target variables are statistically equal to those for the city of São Paulo in 1990. Finally, we characterized abortion by simultaneously detecting the existence of differential behavior for the following:

- Mean abortions per woman, using analysis of variance (ANOVA);

- Abortions per gestation, with the latter defined by convenience as simply the sum of abortions and live births, via the Pearson chi-square statistic;

- Proportion of women with at least one pregnancy, also using Pearson's chi-square.

\section{Analysis of results}

This study's findings emphatically demonstrate the usefulness of the RRT for determining the abortion rate. Using the direct approach, only seven of the 873 interviewees admitted having an induced abortion in 1992 (i.e., one out of a thousand women), while the RRT allowed estimating that 42 per thousand women had an abortion in the year prior to the survey. Extrapolation of the two proportions to Brazil as a whole (based on the premise of similar populations) produces values of 300 thousand and 1.5 million abortions, respectively. This was based on an estimated total of 40 million childbearing-age women in Brazil in 1992 17. The latter value is consistent with estimates published by the Alan Guttmacher Institute 18 . The finding thus proves the advantage of RRT for estimating the induced abortion rate.

The first observation resulting from the analysis of our data is that there were 119 abortions and 2,724 pregnancies during the reproductive lives of the 1,749 interviewees, in other words an average of some 45 abortions per thousand women, with $4.4 \%$ of pregnancies ending in induced abortion. In the previously cited study, conducted in the Vila Madalena neighborhood, the figures were 137 and $8.5 \%$, respectively.
For the 764 married women specifically, there were 34 abortions and 1,754 pregnancies, or an average of approximately 45 abortions per thousand women, with only $2 \%$ of the pregnancies ending in induced abortion and $90 \%$ of the women having become pregnant at least once. For the 658 single women there were 49 abortions per thousand, $18 \%$ of pregnancies having ended in induced abortion, and $16 \%$ of women having become pregnant at least once.

Thus, although single women showed substantially fewer pregnancies as compared to married women, once having become pregnant, single women turned to induced abortion ten times more frequently. However, focusing on the abortion rate per woman, married and single women showed similar figures, with no statistical difference.

These results support the hypothesis consistently defended by Silva ${ }^{9}$, that the abortion per woman rate tends to remain much more stable both in time and space, at around 44 per thousand women. Meanwhile, the abortion-per-pregnancy rate particularly reflects access to contraceptive methods - in terms of availability, motivation to use, and efficacy -, varying substantially according to social conditions and schooling.

\section{Gap between live births and ideal} number of children

Considering that the number of live births is a good indicator for predicting future fertility and that the woman's ideal number of children evaluates whether there is a need to improve access to contraceptive methods 19 , we found it relevant to evaluate the behavior of induced abortion, comparing the actual number of live births to the number of children reported as ideal. We called this the "gap" variable and established the following categories:

a) "Short" gap, when the number of live-born children was less than the total number of children reported as ideal;

b) Equal, when the two variables showed equal values;

c) "Long" gap, when there were more live births than the woman's ideal number of children.

Table 1 shows that some $40 \%$ of the married women - 305 out of 748 - had still not reached their desired total number of children. Slightly more than one-third $(265 / 748)$ had reached what they considered the ideal number, and nearly one-fourth (178/748) had exceeded their desired total fertility. Nevertheless, the trend in induced abortions among married women in relation to both the total number of women and the total number of pregnancies did not show a significant 
Total number of women, total number of abortions, women with history of pregnancy, total number of pregnancies, and some associations between these variables, according to gap between live births and ideal number of children. City of São Paulo, Brazil, 1993.

\begin{tabular}{|c|c|c|c|c|c|c|c|}
\hline & Women & Abortions & $\begin{array}{c}\text { Women with } \\
\text { history of } \\
\text { pregnancy }\end{array}$ & Pregnancies & $\begin{array}{l}\text { Abortions/ } \\
\text { Women (\%०) }\end{array}$ & $\begin{array}{c}\text { Abortions/ } \\
\text { Pregnancies (\%) }\end{array}$ & $\begin{array}{c}\text { Women with } \\
\text { history of } \\
\text { pregnancy/ } \\
\text { women (\%) }\end{array}$ \\
\hline \multicolumn{8}{|l|}{ Married women } \\
\hline \multicolumn{8}{|l|}{ Gap } \\
\hline Short & 305 & 10 & 239 & 347 & 32.8 & 2.9 & 78.4 \\
\hline Equal & 265 & 13 & 265 & 634 & 49.1 & 2.1 & 100.0 \\
\hline Long & 178 & 11 & 178 & 723 & 61.8 & 1.5 & 100.0 \\
\hline Total & 748 & 34 & 682 & 1.704 & 45.5 & 2.0 & 91.2 \\
\hline$\chi^{2}$ & & & & & 3.64 & 105.14 & \\
\hline Descriptive level & & & & & 0.162 & 0.000 & 0.000 \\
\hline \multicolumn{8}{|l|}{ Single women } \\
\hline \multicolumn{8}{|l|}{ Gap } \\
\hline Short & 625 & 31 & 82 & 105 & 50 & 29.5 & 13.1 \\
\hline Equal & 14 & 1 & 11 & 23 & 71 & 4.3 & 78.6 \\
\hline Long & 11 & - & 11 & 46 & - & - & 100.0 \\
\hline Total & 650 & 32 & 104 & 174 & 67.6 & 18.4 & 1.0 \\
\hline$\chi^{2}$ & & & & & 0.87 & 22.06 & 102.39 \\
\hline Descriptive level & & & & & 0.648 & 0.000 & 0.000 \\
\hline
\end{tabular}

difference in terms of the gap $(p=0.162)$. One can thus raise the hypothesis that married women rely on induced abortion not only to maintain what they consider the ideal number of children, but also to space the births.

As expected, the overwhelming majority of single women $(96 \%$, or $625 / 650$ ) had still not reached their desired total number of children. However, there was a different trend by "gap" categories in relation to abortions and pregnancies. The abortion-per-pregnancy rate was high in the "short" gap category (29.5\%; 31/105), negligible for the "equal" gap category (4.3\%), and zero for the "long" gap group. One can argue that the induced abortion rate in relation to pregnancies is considerably higher among single women that have still not reached their desired total number of children as compared to those for whom the desired and actual number of children is the same.

One can claim that among single women the trend in induced abortions in relation to the difference between desired and actual number of children is counter-intuitive. After all, the most sensible thing would be to expect that women would basically use induced abortion when they have already reached what they consider the ideal number of children. Nevertheless, the reported trend corroborates the observation that when a pregnancy occurs outside of a stable marital union, there is a high probably that it will be terminated deliberately.

\section{Age at time of interview}

According to Tietze 20 , the percentage of induced abortions according to the woman's age at the time of the interviews shows that a considerable majority of the abortions - from $58 \%$ to $80 \%$ - occurred in women from 20 to 34 years of age. The same author also noted that the age-specific abortion rates per thousand women in all the populations and years studied were higher for women in one of the five-year brackets from 20 to 34 (i.e., 20-24, 25-29, or 30-34). According to Tietze 20 , underlying fertility, sexual activity, schooling, and family structure explain the concentration of abortions in this age range.

The present survey did not record the date when the pregnancy occurred. It is thus impossible to determine the woman's age at the time, and the only information available was her age at the time of the interview. Working with this variable, we expected an upward trend in the number of abortions, since the women could be expected to accumulate more abortions over the years. But this is definitely not what happened. 
According to Table 2, among single women the highest concentration of abortions was in the $15-24$-year bracket, with $47 \%$ (15/32) of all the abortions. In other words, in single women, nearly half of the abortions were performed before they reached age 25. Meanwhile, in married women the majority of abortions (nearly $80 \%$, or 27/34) occurred after 30 .

Again, the trend in induced abortion among married women did differ either by five-year age bracket or the proportion of pregnancies ending in abortion, although younger women became pregnant substantially less often. In fact, Table 2 shows the statistical significance of the differences in age groups between women with a history of pregnancy as compared to the women as a whole.

Importantly, among single women the abortion rate was highest among younger individuals (15-19 years). Table 2 shows that in this age bracket the women that became pregnant had more abortions than live births as their gestational outcome, with an extremely high rate of 60 abortions per 100 pregnancies. This specific group is further associated with an extremely low proportion of pregnant women, only $3.0 \%$.

\section{Use of contraceptive methods}

A considerable portion of married women, $33.2 \%$ or $254 / 763$, reported not using contraceptive methods at the time of the interview (Table 3). This non-user rate is much lower than that detected by Silva 9 (48.6\%) in 1992, in the Vila Madalena neighborhood. We can thus infer that recent years have witnessed an increase in the proportion of women (especially married women) using contraceptive methods, judging by the following data. In addition, this increase occurred mainly with the more effective methods (oral

Total number of women, total number of abortions, women with history of pregnancy, total pregnancies, and some associations between these variables according to mother's age at time of interview. City of São Paulo, Brazil, 1993.

\begin{tabular}{|c|c|c|c|c|c|c|c|}
\hline & Women & Abortions & $\begin{array}{c}\text { Women with } \\
\text { history of } \\
\text { pregnancy }\end{array}$ & Pregnancies & $\begin{array}{l}\text { Abortions/ } \\
\text { Women (\%०) }\end{array}$ & $\begin{array}{c}\text { Abortions/ } \\
\text { Pregnancies (\%) }\end{array}$ & $\begin{array}{c}\text { Women with } \\
\text { history of } \\
\text { pregnancy/ } \\
\text { women (\%) }\end{array}$ \\
\hline \multicolumn{8}{|l|}{ Married women } \\
\hline \multicolumn{8}{|l|}{ Age } \\
\hline 15-19 & 21 & 1 & 14 & 23 & 47.6 & 4.3 & 66.7 \\
\hline $20-24$ & 74 & - & 61 & 93 & - & - & 82.4 \\
\hline $25-29$ & 110 & 6 & 96 & 176 & 54.5 & 3.4 & 87.3 \\
\hline $30-34$ & 175 & 9 & 154 & 366 & 51.4 & 2.5 & 88.0 \\
\hline $35-39$ & 151 & 9 & 146 & 386 & 59.6 & 2.3 & 96.7 \\
\hline $40-44$ & 131 & 3 & 124 & 390 & 22.9 & 0.8 & 94.7 \\
\hline $45-49$ & 102 & 6 & 100 & 320 & 58.8 & 1.9 & 98.0 \\
\hline Total & 764 & 34 & 695 & 1.754 & 44.5 & 1.9 & 91.0 \\
\hline$\chi^{2}$ & & & & & 5.35 & & 39.75 \\
\hline Descriptive level & & & & & 0.499 & 0.000 & 0.000 \\
\hline \multicolumn{8}{|l|}{ Single women } \\
\hline \multicolumn{8}{|l|}{ Age } \\
\hline $15-19$ & 266 & 6 & 8 & 10 & 22.5 & 60.0 & 3.0 \\
\hline $20-24$ & 186 & 9 & 33 & 40 & 48.3 & 22.5 & 17.7 \\
\hline $25-29$ & 93 & 6 & 26 & 41 & 64.5 & 14.6 & 28.0 \\
\hline $30-34$ & 51 & 4 & 15 & 27 & 78.4 & 14.8 & 29.4 \\
\hline $35-39$ & 28 & 7 & 14 & 34 & 250.0 & 20.6 & 50.0 \\
\hline $40-44$ & 24 & - & 8 & 25 & - & - & 33.3 \\
\hline $45-49$ & 10 & - & 1 & 1 & - & - & 10.0 \\
\hline Total & 658 & 32 & 105 & 178 & 68.0 & 18.0 & 16.0 \\
\hline$\chi^{2}$ & & & & & 3.38 & 18.88 & 80.44 \\
\hline Descriptive level & & & & & 0.559 & 0.004 & 0.000 \\
\hline
\end{tabular}


contraceptives, IUD, and tubal ligation), since they represented some $25 \%$ of the methods used in 1986 in Vila Madalena, but nearly $40 \%$ in the city of São Paulo by 1993. This no doubt occurred due to the proliferation of tubal ligations.

Still, Table 3 shows that the observed trend in the mean number of induced abortions in married women did not show any significant difference in relation to contraceptive methods $(p=0.204)$. Meanwhile, the percentages of abortion per pregnancy and of women with a history of pregnancy were highly significant ( $p=0.001$ and $p=0.0002$, respectively). For married women, the highest proportion of abortions per pregnancy $(2.7 \%)$ occurred in users of effective methods, clearly suggesting that these women only incorporated the methods after reaching the ideal number of children, not least because the majority had undergone tubal ligation.

Meanwhile, the lowest proportion of abortions per pregnancy was among non-users of contraceptive methods, who also showed the lowest proportion of pregnant women (i.e., $86 \%$ versus $94 \%$ for users of contraception). In other words, these married women have certainly still not reached their desired total number of children.
As for the 656 single women, Table 3 shows that the majority (nearly $75 \%$ ) were not using any contraceptive method at the time. Considering that the mean age of single women was 21.5 years, it appears unlikely that the majority had not reached sexual initiation; one can thus suppose that these women are potentially exposed to the risk of becoming pregnant or acquiring HIV infection.

Among single women (Table 3) the trend in the induced abortion differentials is the inverse of that observed previously. The proportion of abortions per pregnancy did not differ among users or between users and non-users of contraceptive methods $(\mathrm{p}=0.141)$. It is thus quite plausible that non-users of contraceptives include women less exposed to the risk of pregnancy, even virgins, who thus fail to exercise effective control over their fertility, but end up using induced abortion in extreme situations. The case of contraceptive users is different. Since they are more exposed to becoming pregnant, they seek to exercise control over their fertility, but turn to induced abortion should their contraceptive method fail. But among users of effective contraceptives the probability of an unwanted pregnancy is certainly lower than among users of other less effective

Total number of married women, total number of abortions, married women with history of pregnancy, total pregnancies, and some associations between these variables according to contraceptive use. City of São Paulo, Brazil, 1993.

\begin{tabular}{|c|c|c|c|c|c|c|c|}
\hline & $\begin{array}{l}\text { Married } \\
\text { women }\end{array}$ & Abortions & $\begin{array}{c}\text { Married women } \\
\text { with history of } \\
\text { pregnancy }\end{array}$ & Pregnancies & $\begin{array}{l}\text { Abortions/ } \\
\text { Married } \\
\text { women (\%) }\end{array}$ & $\begin{array}{c}\text { Abortions/ } \\
\text { Pregnancies } \\
\text { (\%) }\end{array}$ & $\begin{array}{l}\text { Married women } \\
\text { with history of } \\
\text { pregnancy/ } \\
\text { Married women } \\
\text { (\%) }\end{array}$ \\
\hline \multicolumn{8}{|l|}{ Married women } \\
\hline \multicolumn{8}{|l|}{ Contraceptive use } \\
\hline Do not use & 254 & 5 & 218 & 597 & 19.7 & 0.8 & 85.8 \\
\hline Use effective methods & 430 & 27 & 402 & 999 & 62.6 & 2.7 & 93.5 \\
\hline Use other methods & 79 & 2 & 74 & 154 & 25.3 & 1.3 & 93.7 \\
\hline Total & 763 & 34 & 694 & 1.750 & 44.5 & 1.9 & 91.0 \\
\hline$\chi^{2}$ & & & & & 3.18 & 6.92 & 12.18 \\
\hline Descriptive level & & & & & 0.204 & 0.001 & 0.002 \\
\hline \multicolumn{8}{|l|}{ Single women } \\
\hline \multicolumn{8}{|l|}{ Contraceptive use } \\
\hline Do not use & 490 & 13 & 91 & 53 & 26.5 & 24.5 & 10.8 \\
\hline Use effective methods & 118 & 13 & 69 & 41 & 110.7 & 31.7 & 34.7 \\
\hline Use other methods & 48 & 6 & 18 & 11 & 125.0 & 54.5 & 22.9 \\
\hline Total & 656 & 32 & 178 & 105 & 48.7 & 30.5 & 16.0 \\
\hline$\chi^{2}$ & & & & & 6.64 & 3.92 & 42.34 \\
\hline Descriptive level & & & & & 0.002 & 0.141 & 0.000 \\
\hline
\end{tabular}


methods, and one can thus suspect that single women (at the limit) are also opting for irreversible methods like tubal ligation. This hypothesis is confirmed by the fact that the highest proportion of women with a history of pregnancy is precisely among users of effective methods (34.7\%).

\section{Final remarks}

Use of the randomized response technique (RRT) allowed estimating the number of abortions and their characteristics, crucial information for designing adequate and more realistic public policies to meet the demand for contraception. Analysis of data from a survey more than a decade old provided a baseline for subsequent studies to evaluate health programs, fundamentally important for analyzing more recent data and preparing new studies.

According to previous findings and the results of the current study, one can conclude that the most "unwanted" pregnancies occur at the beginning of the woman's reproductive life, or rather, outside the context of a formal relationship, marriage. This analysis reveals that although single women become pregnant at a lower rate than married women, when they do become pregnant they turn to abortion nearly ten times as often as married women. The disadvantage that single women suffer raises cause for concern, not only because they turn to abortion before reaching the ideal number of children, potentially causing future infertility in the process, but also (and especially) because adolescents are particularly affected. According to this study, among single females 15 to 19 years of age, 60 out of 100 pregnancies ended in abortion.

There is no doubt that the increasingly younger age at menarche can lead to earlier sexual initiation and thus a sharper increase in teenage pregnancy and, in turn, more use of induced abortion, at least with the persistently limited range and supply of adequate contraceptive methods during early fertile age.

The number of abortions per single woman proved highly significant as a function of contraceptive use, precisely because of the extremely low figure for non-users. This supports the hypothesis that among non-users of contraceptive methods there is a high proportion of females who have not reached sexual initiation or who have limited sexual activity. As sexual activity intensifies, according to current prospects, there will tend to be more pregnancies and more induced abortions.

Data from the Brazilian National Demographic and Health Survey for 199621 show that more than $70 \%$ of sexually active women reported using contraception. However, as reported in various studies, the limited knowledge on contraceptive use and lack of support from health programs contribute heavily to the inadequate use of contraceptives, causing unwanted side effects 22 and consequent abandonment of the method, besides failures, which can favor induced abortion.

This situation could be avoided by improving the supply of contraceptive services under the Unified National Health System, as provided by Law 9,263 23, thus helping guarantee women's sexual and reproductive rights.

\section{Resumo}

Apresenta-se uma pesquisa realizada na cidade de São Paulo, Brasil, para dimensionar o aborto provocado entre mulheres de 15 a 49 anos. O objetivo é caracterizar a ocorrência do aborto provocado analisando o número ideal de filhos, idade e uso de contraceptivos comparando-se as casadas e solteiras. Mediante sorteio aleatório foram realizadas 1.749 entrevistas, sendo 764 com mulheres casadas, 658 com solteiras e 327 de outras categorias maritais. A análise inclui: a média de abortos por mulher, por meio de análise de variância e proporções de aborto e de gestação, usando-se o teste do qui-quadrado. Verificou-se que a média de abor- tos, 45 por mil, por mulheres casadas não difere da das solteiras. No entanto, as solteiras engravidam numa escala muito menor e, ao engravidarem, recorrem mais largamente ao aborto provocado - enquanto que menos de $2 \%$ das gestações das casadas resultam em aborto provocado, entre aquelas esta cifra supera $18 \%$. A prioridade na área de saúde reprodutiva, sem dúvida, deve ser investir na oferta e divulgação de métodos contraceptivos adequados ao início da vida sexual.

Aborto Induzido; Anticoncepcionais; Saúde Reprodutiva 


\section{Contributors}

R. S. Silva designed the study, collected the data, analyzed the results, and wrote the article. E. M. Vieira participated in the data analysis and elaboration of the article.

\section{References}

1. Rocha MIB, Andalaf Neto J. A questão do aborto: aspectos clínicos, legislativos e políticos. In: Berquó E, organizador. Sexo e vida: panorama da saúde reprodutiva no Brasil. Campinas: Editora Unicamp; 2003. p. 257-318.

2. Martins AL. Mortalidade materna de mulheres negras no Brasil. Cad Saúde Pública 2006; 22:2473-9.

3. Rede Feminista de Saúde. Dossiê aborto: morte preveníveis e evitáveis. Belo Horizonte: Rede Feminista de Saúde; 2005.

4. Ronsmans C, Graham WJ; Lancet Maternal Survival Series Steering Group. Maternal mortality: who, when, where and why. Lancet 2006; 368:1189-200.

5. Grimes D, Benson J, Singh S, Romero M, Ganatra B, Okonofua FE, et al. Unsafe abortion: the preventable pandemic. Lancet 2006; 368:1908-19.

6. Loureiro DC, Vieira EM. Aborto: conhecimento e opinião de médicos dos serviços de emergência de Ribeirão Preto, São Paulo, Brasil, sobre aspectos éticos e legais. Cad Saúde Pública 2004; 20:679-88.

7. Villela WV, Lago T. Conquistas e desafios no atendimento das mulheres que sofreram violência sexual. Cad Saúde Pública 2007; 23:471-5.

8. Talib RA, Citeli MT. Serviços de aborto legal em hospitais públicos brasileiros (1989-2004). Dossiê. São Paulo: Católicas pelo Direito de Decidir; 2005.

9. Silva RS. Aborto provocado: sua incidência e características. Um estudo com mulheres em idade fértil (15 a 49 anos), residentes no sub-distrito de Cidade de São Paulo [Doctoral Dissertation]. São Paulo: Faculdade de Saúde Pública, Universidade de São Paulo; 1992.

10. Fundação Sistema Estadual de Análise de Dados. A fecundidade da mulher paulista. São Paulo: Fundação Sistema Estadual de Análise de Dados; 1994. (Coleção Informe Demográfico, 25)

11. Vieira EM, Badiani R, Fabbro ALD, Rodrigues Junior AL. Características do uso de métodos anticoncepcionais no Estado de São Paulo. Rev Saúde Pública 2001, 36:263-70.

12. Santos EBC. Aborto induzido: ocorrência e características no antigo sub-distrito de Vila Madalena, São Paulo, Brasil-2000 [Masters Thesis]. São Paulo: Universidade Federal de São Paulo; 2005.

13. Alves-Cardoso MR. Comparação entre três métodos de amostragem que visam a estimação da cobertura vacinal [Masters Thesis]. São Paulo: Faculdade de Saúde Pública, Universidade de São Paulo; 1990.

14. Warner SL. Randomized response: a survey technique for eliminating evasive answer bias. J Am Stat Assoc 1965; 60:63-9. 
15. Silva RS. Técnica de resposta ao azar (TRA): uma proposta alternativa. In: Anais do VII Encontro Nacional de Estudos Populacionais. Caxambu: Associação Brasileira de Estudos Populacionais; 1990. p. 517-36.

16. Olinto MTA, Moreira Filho DC. Estimativa de aborto induzido: comparação entre duas metodologias. Rev Panam Salud Pública 2004; 15:331-6.

17. Neupert FR. Nova projeção da população brasileira: hipóteses baseadas em informações recentes. In: Wong LR, Hakkert R, Lima RA, organizadores. Futuro da população brasileira, projeções, previsões e técnicas. São Paulo: Associação Brasileira de Estudos Populacionais; 1987. p. 52-87.

18. The Alan Guttmacher Institute. Aborto clandestino: uma realidade latino-americana. New York: The Alan Guttmacher Institute; 1994.

19. Westoff CF. La fecundidad no deseada en seis países en vías de desarrollo. Perspect Int Planif Fam 1981; 7:104-9.
20. Tietze C. Informe mundial sobre el aborto. Madrid: Instituto de la Mujer, Ministerio de la Cultura; 1987.

21. Sociedade Civil Bem-Estar Familiar no Brasil/Macro International. Pesquisa Nacional de Demografia e Saúde - Brasil 1996. Rio de Janeiro: Sociedade Civil Bem-Estar Familiar no Brasil; 1997.

22. Diaz M, Diaz J. Qualidade de atenção em saúde sexual e reprodutiva: estratégias para mudanças. In: Galvão L, Diaz J, organizadores. Saúde sexual e reprodutiva no Brasil: dilemas e desafios. São Paulo: Editora Hucitec/Population Council; 1999. p. 209-33.

23. Brasil. Lei no. 9.263, de 12 de janeiro de 1996. Regula o $\$ 7$ o do art. 226 da Constituição Federal, que trata do planejamento familiar, estabelece penalidades e dá outras providências. Diário Oficial da União 1996; 15 jan.

Submitted on 13/Mar/2007

Final version resubmitted on 02/Oct/2007 Approved on 23/Nov/2007 